\title{
Correction to: A new in-process material removal rate monitoring approach in abrasive belt grinding
}

\author{
Lijuan Ren ${ }^{1}$. Guangpeng Zhang ${ }^{1} \cdot$ Yuan Wang ${ }^{1} \cdot$ Qian Zhang $^{1} \cdot$ Fei Wang ${ }^{2} \cdot$ Yumei Huang $^{1}$
}

Published online: 17 May 2021

(C) Springer-Verlag London Ltd., part of Springer Nature 2021

Correction to: Int J Adv Manuf Technol

https://doi.org/10.1007/s00170-019-04124-Z

\begin{tabular}{|c|c|c|}
\hline No. & Location and original content & Corrected content \\
\hline 1 & $\begin{array}{l}\text { Line } 1-2 \text { in paragraph } 2 \text { in Section } 5.1 \text { : } \\
\text { “......material removal rate of } 0.08 \mathrm{~g} /(\mathrm{mm} / \mathrm{s}) . "\end{array}$ & “......material removal rate of $0.08 \mathrm{~g} /(\mathrm{mm} \cdot \mathrm{min}) . "$ \\
\hline 2 & $\begin{array}{l}\text { Line } 3-4 \text { in paragraph } 2 \text { in page } 2722 \text { : } \\
\text { "The material removal rates are } 0.036 \text { and } 0.077 \mathrm{~g} /(\mathrm{mm} / \mathrm{s}) \text {, respectively" }\end{array}$ & $\begin{array}{l}\text { "The material removal rates are } 0.036 \text { and } \\
0.077 \mathrm{~g} /(\mathrm{mm} \cdot \mathrm{min}) \text {, respectively" }\end{array}$ \\
\hline 3 & $\begin{array}{l}\text { Line } 2-4 \text { in paragraph } 3 \text { in page } 2722: \text { "And their material removal } \\
\text { rates are } 0.079,0.11 \text {, and } 0.15 \mathrm{~g} /(\mathrm{mm} / \mathrm{s}) \text {, respectively." }\end{array}$ & $\begin{array}{l}\text { "And their material removal rates are } 0.079,0.11 \text {, } \\
\text { and } 0.15 \mathrm{~g} /(\mathrm{mm} \cdot \mathrm{min}) \text {, respectively." }\end{array}$ \\
\hline 4 & $\begin{array}{l}\text { Line } 5-7 \text { in paragraph } 2 \text { in page } 2723: \text { "The material removal } \\
\text { rates are } 0.05,0.082,0.16 \text {, and } 0.22 \mathrm{~g} /(\mathrm{mm} / \mathrm{s}) \text {, respectively" }\end{array}$ & $\begin{array}{l}\text { "The material removal rates are } 0.05,0.082,0.16 \text {, } \\
\text { and } 0.22 \mathrm{~g} /(\mathrm{mm} \cdot \mathrm{min}) \text {, respectively" }\end{array}$ \\
\hline 5 & $\begin{array}{l}\text { Line } 8-9 \text { in paragraph } 3 \text { in page } 2723 \text { : "Their material removal } \\
\text { rates are } 0.33,0.21 \text {, and } 0.05 \mathrm{~g} /(\mathrm{mm} / \mathrm{s}) \text {, respectively." }\end{array}$ & $\begin{array}{l}\text { "Their material removal rates are } 0.33,0.21 \text {, } \\
\text { and } 0.05 \mathrm{~g} /(\mathrm{mm} \cdot \mathrm{min}) \text {, respectively." }\end{array}$ \\
\hline 6 & $\begin{array}{l}\text { Line } 2 \text { in paragraph } 4 \text { in page } 2723: \text { “.......material removal rate } \\
\text { of } 0.15 \mathrm{~g} /(\mathrm{mm} / \mathrm{s}) \text { " }\end{array}$ & “......material removal rate of $0.15 \mathrm{~g} /(\mathrm{mm} \cdot \mathrm{min}) "$ \\
\hline 7 & $\begin{array}{l}\text { X coordinates of the four figures in Fig. } 17 \text { in page } 2725 \text { : } \\
\text { "Material removal rate }\left(\mathrm{g} /\left(\mathrm{mm}^{*} \mathrm{~s}\right)\right) "\end{array}$ & "Material removal rate $(\mathrm{g} /(\mathrm{mm} \cdot \mathrm{min})) "$ \\
\hline
\end{tabular}

Publisher's note Springer Nature remains neutral with regard to jurisdictional claims in published maps and institutional affiliations.

The online version of the original article can be found at https://doi.org/ 10.1007/s00170-019-04124-z.

Guangpeng Zhang

gpzhang@xaut.edu.cn

Lijuan Ren

xkk19881120@163.com

1 School of Mechanical and Precision Instrument Engineering, Xi'an University of Technology, Xi'an 710048, China

2 Hanjiang Machine Tool Co., Ltd., Shaanxi 723003, China 